\title{
Synthesis, Molecular Structure and Antibacterial Activity of Benzylmethyl-4-Methyl-3-Thiosemicarbazone
}

\author{
James A. Mbah*, Godfred A. Ayimele, Elvis N. Eyonganyoh, Emmanuel N. Nfor \\ Department of Chemistry, University of Buea, Buea, Cameroon \\ Email: ^mbah_james@yahoo.com
}

How to cite this paper: Mbah, J.A., Ayimele, G.A., Eyonganyoh, E.N. and Nfor, E.N. (2017) Synthesis, Molecular Structure and Antibacterial Activity of Benzylmethyl4-Methyl-3-Thiosemicarbazone. International Journal of Organic Chemistry, 7, 8390. https://doi.org/10.4236/ijoc.2017.72007

Received: March 22, 2017

Accepted: May 21, 2017

Published: May 24, 2017

Copyright $\odot 2017$ by authors and Scientific Research Publishing Inc. This work is licensed under the Creative Commons Attribution International License (CC BY 4.0).

http://creativecommons.org/licenses/by/4.0/

\begin{abstract}
A novel Schiff base, benzylmethyl-4-methyl-3-thiosemicarbazone (BMM) derived from benzylmethylketone and 4-methylthiosemicarbazide was synthesized and characterized by elemental analysis, spectroscopic methods (IR, ${ }^{1} \mathrm{H}$ NMR, ${ }^{13} \mathrm{C}$ NMR) and physical means. The single crystal structure analysis of the Schiff base reveals that it crystallizes in a monoclinic system in the $\mathrm{P} 2_{1} / \mathrm{c}$ space group. BMM revealed moderate antibacterial activity on three bacterial strains with diameter zone of inhibition of $16 \mathrm{~mm}$ (E. coli), $14 \mathrm{~mm}$ (K. pneumonia) and $13 \mathrm{~mm}$ (S. epidermidis) compared with the standard drug, ciprofloxacin.
\end{abstract}

\section{Keywords}

Benzylmethyl-4-Methyl-3-Thiosemicarbazone, Antibacterial Activity, Crystal Structure

\section{Introduction}

Benzylmethylketone, also known as phenyl-2-propanone occurs as a metabolite of amphetamine via oxidative deamination. It is used as an intermediate in the production of pesticides, rodenticides and anticoagulants [1]. On the other hand, thiosemicarbazones are useful in the medicinal and pharmaceutical fields because of their great significant pharmacological properties such as antibacterial [2] [3] [4], antifungal [2], anti-HIV [5] [6], anticancer [7] [8], antineoplastic [9], anti-inflammatory [10], tuberclostatic [11] and their variable bonding nature. The biological activities of thiosemicarbazones often depend on the parent aldehyde or ketone. In recent years, we have been working on the synthesis of heterocyclic thiosemicarbazone, their metal complexes and biological activities [12] [13]. As part of our ongoing studies, in this paper, we describe synthesis, IR, 
NMR and single crystal X-ray structure of BMM. The antibacterial studies of the novel Schiff base were carried out against: Staphylococcus epidermidis, Bacillus cereus, Escherichi coli and Klebsiella pneumoniae.

\section{Experimental}

\subsection{Materials}

Benzylmethylketone, 4-methylthiosemicarbazide, ethanol and acetic acid were used as purchased without further purification. Elemental analysis was performed on a VARIO EL (Heraeus) analyzer. IR spectrum was obtained from a Perkin-Elmer System 2000 FT-IR spectrophotometer using KBr pellets. The mass spectrum (ESI) was recorded with an FT-IR (APEX II) mass spectrometer from Bruker Daltonics and NMR spectra were run in $\mathrm{CD}_{3} \mathrm{COCD}_{3}$ on a $400 \mathrm{MHz}$ spectrometer. Melting point was recorded on a Gallen-Kamp melting point apparatus and is uncorrected. Elemental analysis was performed on a Thermo Flash EA-1112 Series CHNS-O Elemental Analyzer.

\subsection{Synthesis of Benzylmethyl-4-Methyl-3-Thiosemicarbazone (BMM)}

A suspension of 4-methylthiosemicarbazide $(210 \mathrm{mg}, 0.002 \mathrm{~mol})$ dissolved in 15 $\mathrm{ml}$ ethanol was added to a solution of benzylmethylketone $(0.27 \mathrm{~mL}, 0.002 \mathrm{~mol})$. Five (05) drops of glacial acetic acid were added to the mixture. The reaction mixture (colourless) was allowed to reflux for 6 hours (Scheme 1) at a temperature of $70^{\circ} \mathrm{C}$. The yellowish filtrate which was allowed to cool, formed suitable crystals for X-ray diffraction studies.

Yield: 80\%. Mp: $130^{\circ}$ C. Anal. Calcd for $\mathrm{C}_{11} \mathrm{H}_{15} \mathrm{~N}_{3} \mathrm{~S}$ : C 59.69\%; H 6.83\%; N 18.99\% and S 14.49\%. Experimental: C 56.69\%; H 7.32\%; N $19.71 \%$ and S 14.60\%. IR $\left(\mathrm{KBr}, \mathrm{cm}^{-1}\right): 1545(\mathrm{C}=\mathrm{N}) ; 1122(\mathrm{C}=\mathrm{S}) ; 3225$ and $3330(2 \mathrm{~N}-\mathrm{H}) ; 850$ (N-N). ESI [m/z (\%)]: 221.1 (M, 52); 165.1 (22); 130.0 (100); 91.0 (41). ${ }^{1} H$ NMR $\left.(\delta \mathrm{ppm}): 1.93\left(\mathrm{CH}_{3}-\mathrm{C}=\mathrm{C}\right) ; 3.13\left(\mathrm{CH}_{3}-\mathrm{N}\right) ; 3.59-\mathrm{CH}_{2}-\mathrm{Ar}\right) ; 7.21$ - 7.34 (broad, alkyl substituted benzene ring); $8.15(\mathrm{~N}-\mathrm{H}$ at position 4$)$ and $8.51(\mathrm{~N}-\mathrm{H}$ and position 2). ${ }^{13} \mathrm{C} \operatorname{NMR}(\delta \mathrm{ppm}): 179.9(\mathrm{C}=\mathrm{S}) ; 150.5(\mathrm{C}=\mathrm{N}) ; 137.3$-126.7 (aromatic carbons); $44.7\left(-\mathrm{CH}_{2}-\mathrm{Ar}\right) ; 36.1\left(\mathrm{CH}_{3}-4\right)$ and $14.3\left(\mathrm{CH}_{3}-\mathrm{C}=\mathrm{N}\right)$.

\subsection{Single Crystal X-Ray Diffraction Analysis and Structure Determination}

This was performed using standard procedures as reported by Nfor et al. [14]. Briefly, suitable-single crystal of BMM was mounted in air unto a loop. The data collection for BMM was carried out with a Bruker DUO APEX II CCD diffractometer at temperature controlled using an Oxford cryostream-700. Data reduction and cell refinement were performed using SAINT-Plus, and the space group was determined from systematic absences by XPREP and further justified by the refinement results. Graphite monchromated $\operatorname{MoK} \alpha(\lambda=0.71073 \AA)$ radiation was used. The X-ray diffraction data have corrected for Lorentz-polarization factor and scaled for absorption effects by multi-scan using SADABS. The struc- 
ture was solved by direct method, implemented in SHELXS-97. Refinement procedure by full-matrix least-square method based on $\mathrm{P}^{2}$ values against reflections have been performed by SHELX-97, including anisotropic displacement parameters for all non-H atoms. The positions of hydrogen atoms belonging to the carbon atoms were geometrically optimized by applying a riding model. Calculations concerning the molecular geometry, the affirmation of chosen space groups and the analysis of hydrogen bonds were performed with PLATON. The molecular graphic was done with ORTEP-3 and Mercury (version 3.0).

\subsection{Antimicrobial Activity}

The antibacterial activity of the BMM was determined using a modified KirbyBauer disc diffusion method [15]. The antibacterial activity was done by using gram +ve organisms: Staphylococcus epidermidis and Bacillus cereus as well as gram -ve organisms: Escherichi coli and Klebsiella pneumoniae. Ciprofloxacin was used as the standard. The percent activity index for the antibacterial was calculated as reported in literature [16].

\section{Results and Discussion}

The condensation reaction between benzylmehtylketone and 4-methylthiosemicarbazide gave benzylmethyl-4-methyl-3-thiosemcarbazone in good yield (Scheme 1).

\subsection{Elemental Analyses}

The elemental analysis for $\mathrm{C}, \mathrm{H}, \mathrm{N}$ and $\mathrm{S}$ revealed that the calculated and experimental data for the Schiff base are in good agreement suggesting the high percent purity of the compound which was further confirmed by mass spectrometry.

\subsection{Infrared Spectrum}

The infrared spectrum (Figure 1) was taken in $4000-400 \mathrm{~cm}^{-1}$ region. Two bands between 3330 and $3225 \mathrm{~cm}^{-1}$ representing stretching frequencies for the two N-H groups. Two bands between 690 and $760 \mathrm{~cm}^{-1}$ indicating the presence of a monosubstituted benzene ring. Other important bands were observed at $1545 \mathrm{~cm}^{-1}(\mathrm{C}=\mathrm{N})$ and $1122 \mathrm{~cm}^{-1}(\mathrm{C}=\mathrm{S})$.

\section{3. ${ }^{1} \mathrm{H}$ NMR Spectrum}

The ${ }^{1} \mathrm{H}$ NMR spectrum (Figure S1) of benzylmethyl-4-methyl-3-thiosemcarba-

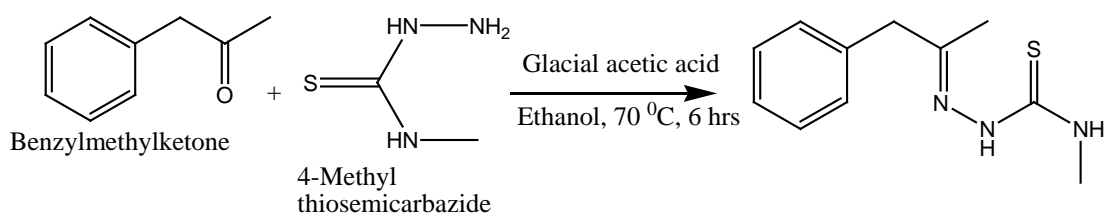

Scheme 1. Synthesis of benzylmethyl-4-methyl-3-thiosemicarbazone. 
zone was recorded in $\mathrm{CD}_{3} \mathrm{COCD}_{3}$. Prominent peaks were observed at $1.93 \mathrm{ppm}$ corresponding to a methyl group attached to an $\mathrm{sp}^{2}$ carbon, $3.13 \mathrm{ppm}$ indicating a methyl group on a nitrogen atom and a broad singlet between $7.21-7.34 \mathrm{ppm}$ suggesting that the aromatic ring is substituted by an alkyl group [Supplementary file].

\section{4. ${ }^{13} \mathrm{C}$ NMR Spectrum}

The ${ }^{13} \mathrm{C}$ NMR spectrum (Figure S2) of benzylmethyl-4-methyl-3-thiosemcarbazone was recorded in $\mathrm{CD}_{3} \mathrm{COCD}_{3}$. The most deshielded peak appeared at 179.9 ppm and was attributed to $\mathrm{C}=\mathrm{S}$, followed by a peak at $150.5 \mathrm{ppm}$ which was assigned to $\mathrm{C}=\mathrm{N}$. Signals for the aromatic carbon atoms were observed in the range, 137.3 - $126.7 \mathrm{ppm}$ while the methylene carbon atom directly attached to the aromatic ring was seen at $44.7 \mathrm{ppm}$.

\subsection{Single Crystal X-Ray Crystallography}

The molecular structure of the Schiff base is shown in Figure 2 along with the atomic numbering scheme. The Schiff base crystallises in the monoclinic system in space group $\mathrm{P} 2{ }_{1} / c$. The unit cell dimensions are $\mathrm{a}=10.1942$ (9) $\AA$, $\mathrm{b}=11.9005$ (10 $\AA$ and $\mathrm{c}=10.5254$ (10) $\AA$ with the cell angles being $\alpha=90.00, \beta=113.089$ (2) and $\chi=90.00$.

The crystal structure of the molecule is in line with the IR, NMR and elemental analysis data of the molecule. It shows the possibility of hydrogen bonding (Figure 3).

\subsection{Antimicrobial Activity of \\ Benzylmethyl-4-Methyl-3-Thiosemcarbazone (BMM)}

The antibacterial activity of BMM as shown on Table 1.

$\mathrm{BMM}$ was found to be moderately active against three strains of bacteria. The

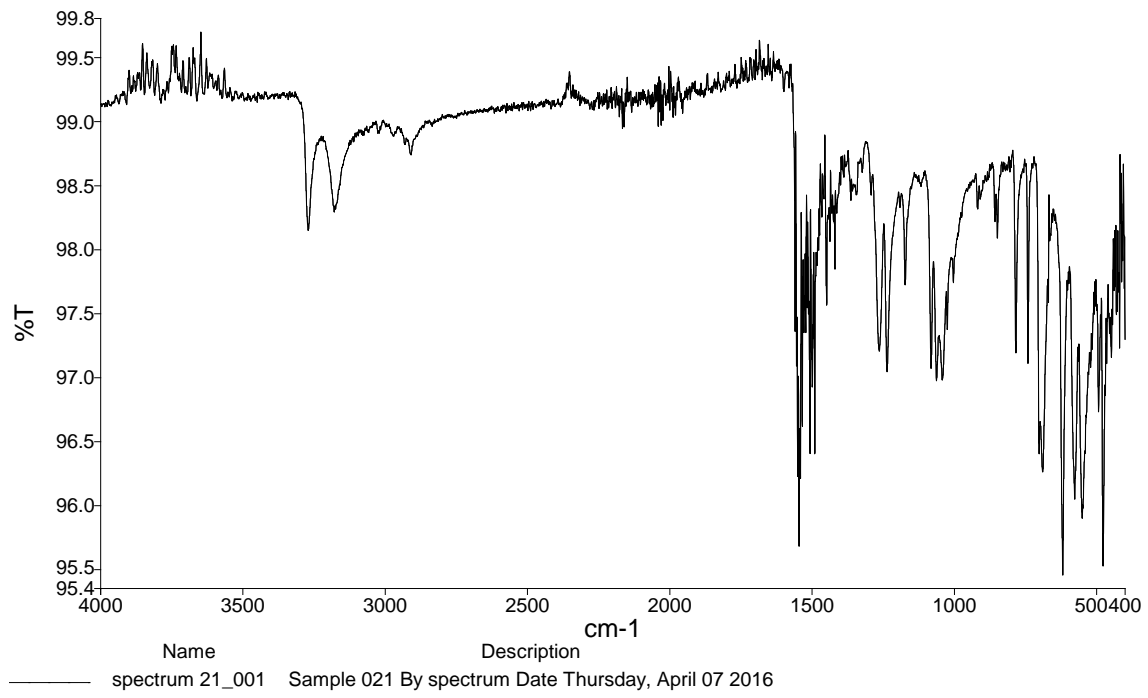

Figure 1. IR spectrum of BMM. 
antibacterial activity of BMM may be attributed to the presence of toxophorically important imine group $(-\mathrm{C}=\mathrm{N})$ where the mode of action of such compounds may involve the formation of hydrogen bond through azomethine group with the active centre of the cell constituents, thereby resulting in the interference with normal cell processes [17]. This is the first report of benzylmethyl-4-methyl-3-thiosemicarbazone on bacteria. Given the promiscuity of thiosemicarbazones, BMM will be screened on other pathogens such as malaria and onchocerciasis.

\section{Conclusion}

A novel compound, benzylmethyl-4-methyl-3-thiosemcarbazone (BMM) de-

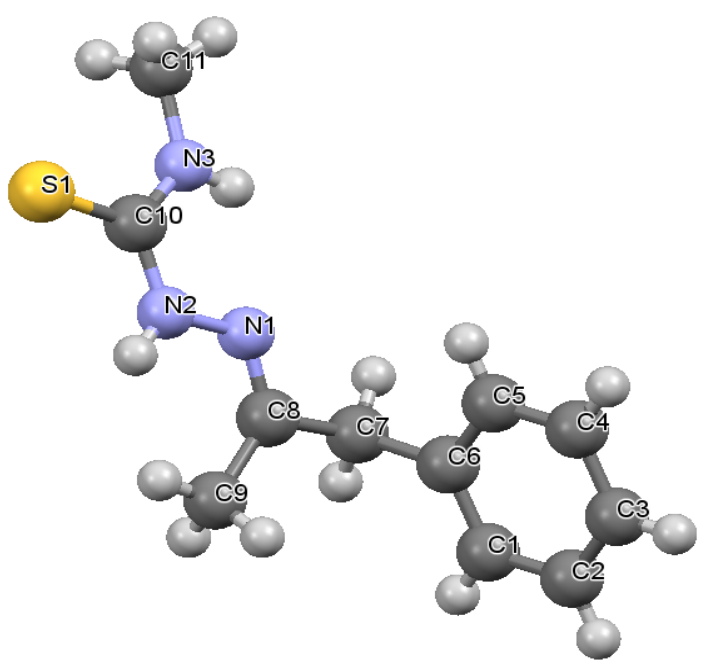

Figure 2. Crystal structure of BMM with atom numbering scheme.

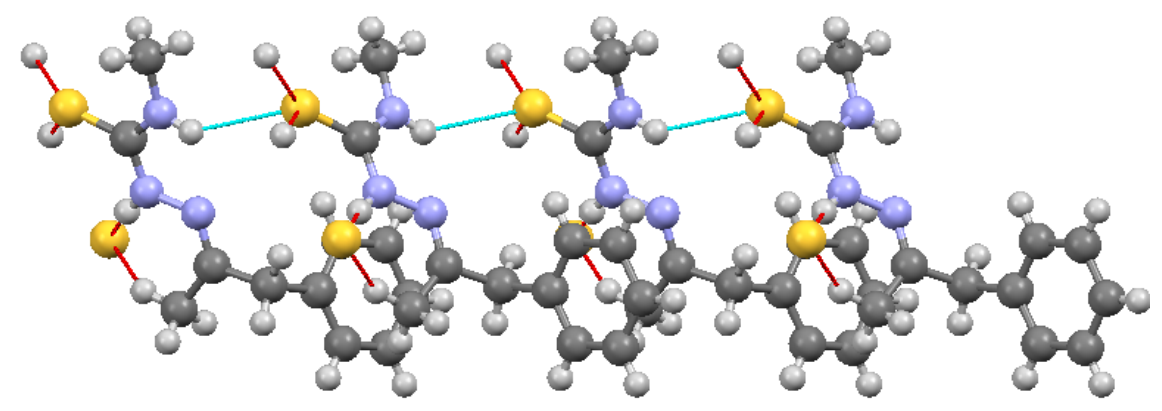

Figure 3. Intermolecular hydrogen bonding of the Schiff base.

Table 1. Diameter of inhibition zone of bacterial strains by BMM at disc potency of 100 $\mu \mathrm{g} / \mathrm{mL}$

\begin{tabular}{cccccc}
\hline \multirow{2}{*}{ Compound } & Conc $(\mu \mathrm{g} / \mathrm{mL})$ & \multicolumn{5}{c}{ Diameter of inhibition zone $(\mathrm{mm})$} \\
\cline { 3 - 6 } & 100 & EC & KP & BC & SE \\
\hline $\begin{array}{c}\text { BMM } \\
\text { Ciprofloxacin }\end{array}$ & 16 & 14 & NA & 13 \\
(standard) & 100 & 26 & 23 & 26 & 28 \\
\hline
\end{tabular}

$\mathrm{NA}=$ Not Active; $\mathrm{EC}=$ Escherichi col; $\mathrm{KP}=$ Klebsiella pneumonia $; \mathrm{BC}=$ Bacillus cereus $; \mathrm{SE}=$ Staphylococcus epidermidis and BMM = benzylmethyl-4-methyl-3-thiosemicarbazone. 
rived from benzylmethylketone and 4-methylthiosemicarbazide was synthesized and characterized by spectroscopic and physical means. The crystal structure of BMM is being reported for the first time. BMM revealed moderate antibacterial activity on three bacterial strains with diameter zone of inhibition of $16 \mathrm{~mm}(E$. coli), $14 \mathrm{~mm}$ ( $K$. pneumonia) and $13 \mathrm{~mm}$ ( $S$. epidermidis) for the first time, suggesting that such compounds could be exploited as antibacterial leads. In vivo screening and toxicity studies will be done to ascertain its possibility as a lead for drug or prodrug development.

\section{Acknowledgements}

We greatly acknowledge Prof. Susan Bourne, of the State Center of Supramolecular Chemistry, Cape Town University for sponsoring the spectral analyses of this compound. We thank Dr. Agha Innocent of Bamenda General Hospital for the antibacterial studies.

\section{References}

[1] Gionani, S.D., Varriale, A., Marzullo, V.M., Ruggiero, G., Staiano, M., Secchi, A., Pierno, L., Fiorello, A.M. and D’Auria, S. (2012) Determination of Benzylmethylketone-A Commonly Used Precursor in Amphetamine Manufacture. Analytical Methods, 4, 3558-3564. https://doi.org/10.1039/c2ay25772f

[2] Parul, N., Subhangkar, N. and Mahato, A. (2012) Antimicrobial Activity of Different Thiosemicarbazone Compounds against Microbial Pathogens. International Research Journal of Pharmacy, 3, 350-363.

[3] Abou-Mehla, K.S. and Faruk, H. (2008) Bimetallic Complexes of Schiff Base Bis-[4-hydroxycoumarin-3-yl]-1N,5N-thiocarbohydrazone as a Potentially Dibasic Pentadentate Ligand. Synthesis, Spectral and Antimicrobial Properties. Journal of the Iranian Chemical Society, 5, 122-134. https://doi.org/10.1007/BF03245825

[4] Patil, S.A., Naik, V.H., Kulkarni, A.D. and Badami, P.S. (2010) DNA Cleavage, Antimicrobial, Spectroscopic and Fluorescence Studies of $\mathrm{Co}(\mathrm{II}), \mathrm{Ni}(\mathrm{II})$ and $\mathrm{Cu}(\mathrm{II})$ Complexes with SNO Donor Coumarin Schiff Bases. Spectrochimica Acta A, 75, 347-354. https://doi.org/10.1016/j.saa.2009.10.039

[5] Teytz, Y., Ronen, D., Vansover, A., Stematsky, T. and Riggs, J.L. (1994) Inhibition of Human Immunodeficiency Virus by N-methylisatin-beta $4{ }^{\prime}: 4^{\prime}$-Diethylthiosemicarbazoneand N-Allylisatin-beta4':4'-diallythiosemicarbazone. Antiviral Research, 24, 305-314. https://doi.org/10.1016/0166-3542(94)90077-9

[6] Teytz, Y., Barko, N., Abramoff, M. and Ronen, D. (1994) Relationships between Structure and Antiretroviral Activity of Thiosemicarbazone Derivatives. Chemotherapy, 40, 195-200. https://doi.org/10.1159/000239192

[7] Hall, I.H., Wong, O.T. and Chapman, J.M. (1995) Cytotoxicity of Imides-N-alkyl Semicarbazones, Thiosemicarbazones, Acetyl Hydrazones and Related Derivatives. Anticancer Drugs, 6, 147-153. https://doi.org/10.1097/00001813-199502000-00017

[8] Tahmeena, K., Rumana, A., Seema, J. and Khan, A.R. (2015) Anticancer Potential of Metal Thiosemicarbazone Complexes: A Review. Der Chemica Sinica, 6, 1-11.

[9] Liu, M., Lin, T. and Sartorelli, A.C. (1992) Synthesis and Antitumor Activity of Amino Derivatives of Pyridine-2-Carboxaldehyde Thiosemicarbazone. Journal of Medicinal Chemistry, 35, 3672-3677. https://doi.org/10.1021/jm00098a012

[10] Mignot, A., Miocque, M., Binet, P., Rapin, J.R., Rinjard, P., Roux, M., Cals, M.J. and 
Ekindjian, J.C. (1980) Thiosemicarbazones d'aldéhydes Aromatiques Antiinflammatoires: Pharmacologie, étude pharmacocinétique preliminaire, action sur le fibroblaste en culture. European Journal of Medicinal Chemistry, 15, 33-40.

[11] Bemstein, J., Yale, H.L., Losee, K., Holsing, M., Martins, J. and Lott, W.A. (1951) The Chemotherapy of Experimental Tuberculosis. III. The Synthesis of Thiosemicarbazones and Related Compounds. Journal of the American Chemical Society, 73, 906-912. https://doi.org/10.1021/ja01147a007

[12] Nfor, E.N., Esemu, S.N., Ayimele, G.A., Ededet, A.E., Iniama, G.E. and Offiong, E.O. (2011) Copper (II) and Nickel (II) Complexes of 4-Phenylsemicarbazones: Synthesis, Stereochemistry and Antimicrobial Activity. Bulletin of the Chemical Society of Ethiopia, 25, 361-370. https://doi.org/10.4314/bcse.v25i3.68668

[13] Majoumo-Mbe, F., Nde, D.T., Mukoko, I.N., Offiong, E.O. and Nfor, E.N. (2016) Synthesis, Crystal and Molecular Structure of Manganese (II) Complex of 2-Acetylpyridine N(4) Ethylthiosemicarbazone. Communications in Inorganic Synthesis, 4, 5-11.

[14] Nfor, E.N., Ahmad, H., Majoumo-Mbe, F., Njah, I.N., Offiong, E.O. and Bourne, S. (2013) Synthesis, Crystal Structure and Antifungal Activity of a Ni(II) Complex of a New Hydrazone Derived from Antihypertensive Drug Hydralazine Hydrochloride. Polyhedron, 63, 207-213. https://doi.org/10.1016/j.poly.2013.07.028

[15] Bauer, A.W., Kirby, W.M., Sherris, C. and Turck, M. (1966) Antibiotic Susceptibility Testing by a Standardized Single Disc Method. American Journal of Clinical Pathology, 45, 493-499.

[16] El-Sherif, A.A., Shoukry, M.M. and Abobakr, L.O. (2013) Bivalent Transition Metal Complexes of Cetirizines: Spectroscopic, Equilibrium Studies and Biological Activity. Spectrochimica Acta $(A), 112,290-300$.

[17] El-Sherif, A.A. and Shoukry, M.M. (2007) Ternary Copper(II) Complexes Involving 2-(aminomethyl)-benzimidazole and Some Bio-Relevant Ligands. Equilibrium Studies and Kinetics of Hydrolysis for Glycine Methyl Ester under Complex Formation. Inorganica Chimica Acta, 360, 473-487. 


\section{Supplementary File}

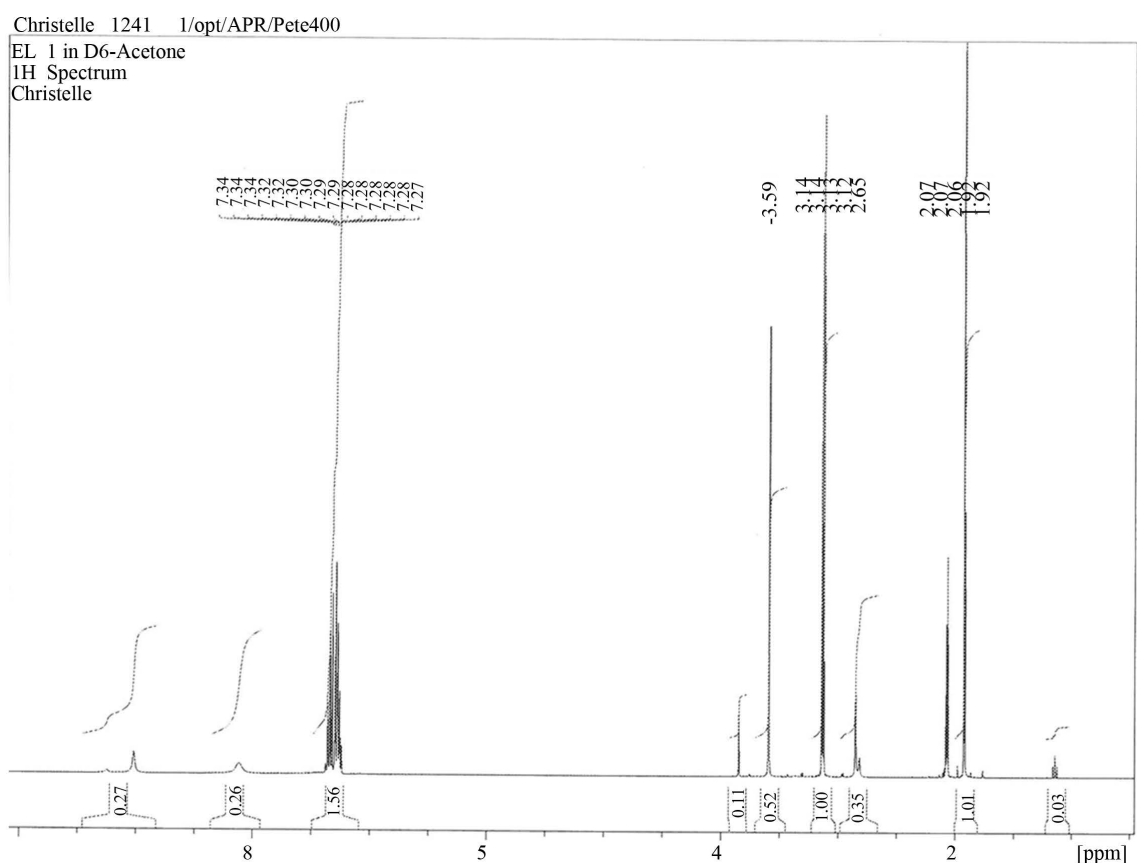

Figure S1. ${ }^{1} \mathrm{H}$ NMR spectrum of BMM.

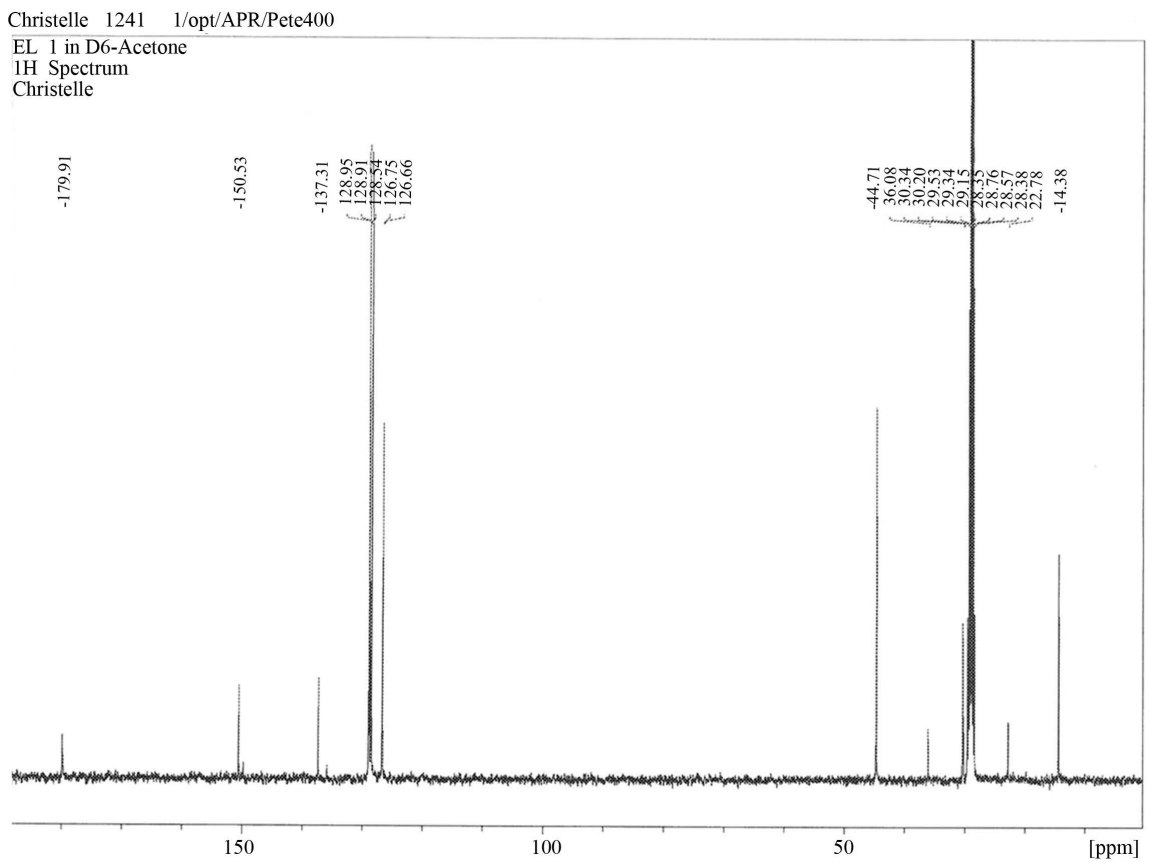

Figure S2. ${ }^{13} \mathrm{C}$ NMR spectrum of BMM. 
Submit or recommend next manuscript to SCIRP and we will provide best service for you:

Accepting pre-submission inquiries through Email, Facebook, LinkedIn, Twitter, etc. A wide selection of journals (inclusive of 9 subjects, more than 200 journals)

Providing 24-hour high-quality service

User-friendly online submission system

Fair and swift peer-review system

Efficient typesetting and proofreading procedure

Display of the result of downloads and visits, as well as the number of cited articles Maximum dissemination of your research work

Submit your manuscript at: http://papersubmission.scirp.org/

Or contact ijoc@scirp.org 